\title{
Preparing Teachers for Inclusion: Attitudes, Challenges and Concerns of General Education Novice Teachers from the Perspective of a Credential Program Training Teacher
}

\author{
Chao Sun \\ Shanghai Normal University Tianhua College \\ Shanghai, China
}

\begin{abstract}
The current study aims to explore the attitudes, challenges and concerns of novice teachers towards working in an inclusive education classroom and the degree of which their training has adequately prepared them to teach students with special needs. This qualitative research reports that compared with their experienced colleagues, novice teachers are more receptive to inclusive education but they are faced with challenges. Pre-service training programs have prepared novice teachers with some skills and confidence in inclusion but more in-service training are required.
\end{abstract}

Keywords-novice teacher; inclusive education; attitude; challenge; concern

\section{INTRODUCTION}

Inclusive education has been one of the most key strategies to ensure education for all children worldwide for decades. In the U.S., this was originally enacted by Congress in 1975 . "The Individuals with Disabilities Education Act (IDEA) ensures that all children with disabilities are entitled to a free appropriate public education to meet their unique needs and prepare them for future education, employment, and independent living." [1]

Proponents of inclusive education firmly believe that all the students with special needs should participate in regular classrooms with their peers. And the key concept in inclusive education is that schools should accommodate all students regardless of their differences in abilities.

Success in inclusive education involves many facets: teacher preparation including teachers' knowledge and skills of implementing inclusive education; policy factors, school climate, sufficient resource supplies, etc. Compared with teachers with several years of experiences, novice teachers (teachers with less than 3 years of experiences) are undergoing a critical period in their career development. Their attitudes and concerns towards their teaching career play important roles in their professional development. The first years of teaching are an important phase in a teacher's professional growth because the classroom experiences of novice teachers may either encourage or inhibit a lasting commitment to effective teaching [2]. The dropout rate of novice teachers is problematically high worldwide [3]. For example, nearly half of American novice teachers leave the teaching profession within the first five years [4].

The current study aims to explore the attitudes, challenges and concerns of general education novice teachers towards working in an inclusive education classroom and the degree to which their training has adequately prepared them to teach students with special needs from the perspective of a preservice credential program trainer. Compared with pre-service teachers, novice teachers are now in their teaching jobs and their teaching experiences might be different from what they previously thought. And different from their experienced colleagues, novice teachers are still shaping their attitudes and teaching beliefs. In literature there has been some studies researching the attitudes and self-efficacy of pre-service and in-service teachers towards inclusive education. Concerning the studies of in-service teachers, some of the research focused on the teachers with many years of experiences while many others did not differentiate between new teachers and experienced teachers. Due to the special characteristics of novice teachers, the current study equips itself with appropriate rationalities.

Two research questions are addressed in the current study: 1. What are the attitudes of novice teachers towards including students with special needs in their general education classrooms, their concerns and challenges? 2. How well do pre-service training programs prepare novice teachers to teach students with special needs in an inclusive setting?

\section{LITERATURE REVIEW}

Inclusive education is defined by The National Center on Educational Restructuring and Inclusion (1995) as "providing to all students, including those with significant disabilities, equitable opportunities to receive effective educational services, with the needed supplementary aids and support services, in age appropriate classrooms in their neighborhood schools, in order to prepare students for productive lives as full members of society." [5] 
While inclusive education remains a controversial issue, boundless studies have shown positive outcomes of incorporating students with special needs into regular classrooms. In their review study of the impact of inclusion on students with and without disabilities, Salend and Duhaney indicated that students' academic performance was found equal to or even better in inclusive settings for general education students, even those considered to be high achievers [6]. Walter-Thomas, Bryant and Land found in a three-year study of inclusive programming at the elementary level that when a co-teaching model was implemented, both students with disabilities and low-achieving general education students experienced improvements in social skills and all students experienced increases in self-esteem related to their abilities and accomplishments [7]. Ritter, Michel and Irby discussed in their article that the mere fact of attending a regular classroom instead of a special one would enable students with disabilities experience increased self-esteem [8].

As more and more students with special needs are included in the general education classrooms, the attitudes of general education teachers towards inclusion become very important [9]. Previous studies have revealed varied results when assessing teacher attitudes towards inclusion of students with special needs into the general classroom. Sharma, Forlin, Loreman and Earle conducted an international comparison study of pre-service teachers' attitudes, concerns and sentiments about inclusive education [10]. The paper reports the perceptions of pre-service teachers prior to their work involving specifically on inclusive education in universities located in Australia, Canada, Hong Kong China and Singapore. The study showed that compared with students in the East represented by Hong Kong China and Singapore in this study, students from western countries participated in the study represented by Australia and Canada showed more positive sentiments and attitudes towards students with disabilities.

In the study by Rheams and Bain, teachers' perceptions and attitudes towards social interaction interventions in early childhood settings are investigated [11]. Self-contained classroom and inclusive classroom teachers were enrolled in the study and variables that might interfere with perceived acceptability, feasibility, and current use of interventions were explored.

Through the review of other studies, Scruggs and Mastropieri found that $54.4 \%$ of the teachers in various studies they reviewed showed supportive attitudes towards inclusion of students with special needs [12]. Shechtman, Reiter and Schanin showed that when asked directly about the question of whether they are pro-inclusion, two-thirds answered positively to the question [13]. Studies also examined the correlation between factors influencing teacher attitudes towards inclusion, such as the type and severity of students' needs without agreement on which needs actually promote a more positive attitude among teachers [14-15].

From the previous research it is perceived that teachers' attitudes towards inclusion have been approached from different perspectives. Furthermore, teacher attitudes towards inclusion were also explored with other factors: factors influencing teacher attitudes such as demographic features, teacher self-efficacy, etc. Meanwhile, with most studies showing positive teacher attitudes towards inclusion of students with special needs, many of the studies exhibited a sense of discomfort and reservation towards inclusion [16-17].

By reviewing literature it is easily noticed that few studies have been conducted considering the attitudes of general education novice teachers towards inclusion. Therefore, the present study tries to focus on the group of novice teachers and tries to explore novice teachers' attitudes and concerns towards inclusion. In addition, the preparedness of novice teachers in their pre-service credential programs to teach in inclusive settings is also taken into consideration.

\section{MethodOLOGY}

To answer the two research questions, a qualitative methodology of case study was adopted. Case study is the study of a case within a real-life, contemporary context or setting. It aims at an in-depth description and analysis of a case or multiple cases. Case study is an appropriate approach in this study since the participant under investigation is of unique characteristics. Aimed at exploring the attitudes of novice teachers towards inclusion in general education, the current study serves as the first step to investigate the credential program training teacher's perceived attitudes of novice teachers in general education classrooms, their challenges and concerns, and the functions of credential programs which prepare pre-service teachers for the future teaching careers.

\section{A. Data Collection}

This study was an attempt to understand inclusion from the perspective of a credential program trainer. Individual indepth interview was the main source of data collection. The interview protocol for this study consisted of open-ended, semi-structured questions designed to initiate conversations with the participant. The interview questions clustered around the research questions set for this study. In addition to interview, the study also used documentation for the purpose of triangulation.

The interview was conducted in English and was taperecorded with the consent of the participant. In addition, the interviewer took notes of important points through the interview process.

\section{B. Selection of the Participant}

The respondent of the current study is a teacher who works for the School of Education in a university in America. She is in charge specifically of students who are pursuing their Education Specialist credential. She has worked as an educator in special education for 12 years including four years experiences of training and observing special education and general education pre-service teachers. With clear direction and purpose, the study used purposeful and convenience sampling to find one interviewee who met the requirements of the study. 


\section{Data Analysis}

For the data analysis, after the interview, all the conversations were transcribed verbatim. Since this is a single case study, the interview transcript was reviewed carefully and coded to identify all the themes emerged from it. All the emerging themes were organized around the research questions established for this study.

\section{FINDINGS AND DISCUSSIONS}

Three major themes emerged in the interview were general education novice teachers' attitudes towards inclusion; their challenges and concerns and their preparation to implement inclusion. These three themes were coded as theme 1, theme 2 and theme 3 respectively.

\section{A. Theme 1: Attitudes of Novice Teachers towards Inclusion}

Analyses of the interview transcripts showed that compared with experienced teachers, novice teachers are in general more receptive to including students with special needs in their general education classrooms. As new teachers with limited teaching experience, their attitudes towards inclusion are also influenced by multiple factors such as degree of students' disabilities, their abilities to address students' behavioral problems, etc. At the initial stage of career development and after instant training on special education, new teachers are usually higher in self-efficacy and try to present better performances. By exploring variables influencing or predicting teachers' general attitudes towards inclusion, school characteristics, level of teaching experience, sense of personal efficacy predict attitudes towards inclusion [18-21]. Level of teaching experience has been found to be associated with both higher acceptances of students with disabilities and less willingness to teach these students [19-20] Novice teachers may be losing their pre-service idealism in dealing with the challenges of inclusion as they accumulate teaching experience. Pre-service and new general education teachers in particular express anxiety about interacting with and teaching students with disabilities [22-23]. Hence, the research exhibits conflicts in the first years of teaching among novice teachers in that they are showing positive attitudes towards inclusion while being bothered by concerns of inabilities or lack of adequate skills implementing inclusion.

\section{B. Theme 2: Challenges and Concerns of Novice Teachers}

As mentioned above, most novice teachers are showing receptive attitudes towards inclusion while inevitably being faced with challenges. According to respondent of the current study, the greatest concern of novice teachers in inclusive environment is the disruptive behaviors of students. In addition, novice teachers are also concerned with insufficient resources such as administrative and paraprofessional support, planning and instructional time, and class load [11][24]. Inservice training may help release worries of new teachers and improvement of school environment would facilitate collaborative roles among teachers.

\section{Theme 3: Novice Teachers' Preparation to Implement Inclusion}

As classrooms become more inclusive, teachers need to get prepared for more diverse student population. Research findings suggest that universities and their students will become pivotal in ensuring the success of inclusion [10][25]. As a teacher who helps students pursuing their Education Specialist credential, the respondent of the current study shows that the levels of programs vary across nation in preparing teachers for future inclusion classrooms. In the university she works with, students who intend to become teachers in the future must take at least one course in special education. Also, there are courses to address behavior problems and teach teachers behavior techniques. In addition, student-teaching seminar held every week is also an effective way to help new teachers out, to bring them to the structure of the classroom, to bring them on board when they are new, and teach them how to deal with difficulties. According to Nes (2000), the way in which pre-service teachers are trained through their initial course seems to play a critical role in how they employ inclusive education strategies when teaching fulltime in schools [26]. Although with all the importance and necessity of training for pre-service teachers, it is surprising that some teacher education courses offer little in the form of inclusive education and/or even fail to address key aspects of inclusion. To elaborate, many new teachers express apprehension in regards to their ability to teach students with diverse needs in general education classrooms and apportion blame on their preparation for inclusion. For many pre-service teachers their only exposure to the area of inclusive education is an introductory inclusive education subject included in their teacher education course [23]. Research has shown that these introductory inclusive education subjects can have a positive influence on the attitudes and confidence of those studying these subjects [10][27][28]. Since qualities of training programs vary across the nation, to ensure successful implementation of inclusion in general education classrooms, in-service mentoring and collaboration would also be helpful as a supplement of pre-service training [29-31].

\section{CONCLUSION}

The study answers the two research questions of novice teachers' attitudes towards inclusion and their preparedness of inclusive classrooms through pre-service training programs. Novice teachers show positive attitudes towards inclusion while being faced with concerns. And training programs have prepared student teachers with some skills and confidence in inclusion but mentoring and collaboration are also necessary to ensure successful inclusion.

In the future research, variables predicting teachers' attitudes towards inclusion such as school characteristics, years of experiences, teachers' sense of self-efficacy should be taken into account. Meanwhile, views and perceptions of novice teachers themselves should be collected to get a more direct and comprehensive view about their attitudes and concerns in inclusive settings. 


\section{REFERENCES}

[1] Http://Www.Apa.Org/About/Gr/Issues/Disability/Idea.Aspx

[2] I.S. Ginns, and A. Heirdsfield, and B. Atweh, and J.J. Watters, "Beginning teachers becoming professionals through action research," Educational Action Research Journal, vol.9, pp.109-131, 2001

[3] J.Y. Hong, "Pre-service and beginning teachers' professional identity and its relation to dropping out of profession," Teaching and Teacher Education, vol.26, pp.1530-1543, 2010.

[4] S. Duffield, "Safety net or free fall: The impact of cooperating teachers," Teacher Development, vol. 10, pp.167-178, 2006.

[5] City University of New York, NY. National Center on Educational Restructuring and Inclusion, p.5,1994

[6] S.J. Salend, and L.G. Duhaney, "The impact of inclusion on students with and without disabilities and their educators," Remedial \& Special Education, vol. 20, pp.114-127, 1999.

[7] C. Walter-Thomas, and M. Bryant, and S. Land, "Planning for effective co-teaching: The key to successful inclusion," Remedial and Special Education, vol. 17, pp.255-264, 1996.

[8] C.L. Ritter, and C.S. Michel, and B. Irby, "Concerning inclusion: Perceptions of middle school students, their parents, and teachers," Rural Special Education Quarterly, vol.18, pp.10-17, 1999.

[9] J. Siegel, "Regular education teachers' attitudes toward their mainstreamed students," Paper presented at the annual Convention of the Council for Exceptional Children, Baltimore, MD, 1992.

[10] U. Sharma, and C. Forlin, and T. Loreman, and C. Earle, "Pre-service teachers' attitudes, concerns and sentiments about inclusive education: An international comparison of novice pre-service teachers," International Journal of Special Education, vol.21, pp.80-93, 2006.

[11] T.A. Rheams, and S.K. Bain, "Social interaction interventions in an inclusive era: Attitudes of teachers in early childhood self-contained and inclusive settings," Psychology in the Schools, vol.42, pp.53-63, 2005.

[12] T.E. Scruggs, and M.A. Mastropieri, "Teacher perceptions of mainstreaming/inclusion, 1958-1995: A research synthesis," Exceptional Children, vol.63, pp.59-74, 1996.

[13] Z. Shechtman, and S. Reiter, and M. Schanin, "Intrinsic motivation of teachers and the challenge of mainstreaming: an empirical investigation," Special Services in the Schools, vol.7, pp.107-124, 1993.

[14] L.C. Soodak, and D.M. Podell, "Teacher efficacy and student problem as factors in special education referral," Journal of Special Education, vol.27, pp.66-81, 1993.

[15] F. L. Wilczenski, "Measuring an attitudes toward inclusive education," Psychology in Schools, vol.29, pp.306-312, 1992.

[16] W. King, and A. Edmunds, "Teachers' perceived needs to become more effective inclusion practitioners: A single school study," Exceptionality Education Canada, vol.11, pp.3-23, 2001.

[17] P.Stanovich, and A. Jordan, "Preparing general educators to teach in inclusive classrooms: Some food for thought," Teacher Educators,vol.37, pp.178-185, 2002.

[18] A. K. Van Reusen, and A. R. Shoho, and K.S. Barker, "High school teacher attitudes toward inclusion," The High School Journal, vol.84, pp.7-20, 2000.

[19] B.G. Cook, "Inclusive teachers' attitudes toward their students with disabilities: A replication and extension," The Elementary School Journal, vol.104, pp.307-320, 2004.

[20] J. McLeskey, and N.L. Waldron, and T. H. So, and K. Swanson, and T. Loveland, "Perspectives of teachers toward inclusive school programs," Teacher Education and Special Education, vol.24, pp.108-115, 2001.

[21] H. Lifshitz, and R. Glaubman, and R. Issawi, "Attitudes towards inclusion: The case of Israeli and Palestinian regular and special education teachers," European Journal of Special Needs Education, vol.19, pp.171-190, 2004.

[22] A. Carroll, and C. Forlin, and A. Jobling, "The impact of teacher training in special education on the attitudes of Australian preservice general educators towards people with disabilities," Teacher Education Quarterly, vol.30, pp.65-79, 2003.
[23] T.P. Lombardi, and N.J. Hunka, "Preparing general education teachers for inclusive classrooms: Assessing the process," Teacher Education and Special Education, vol.24, pp.183-197, 2001.

[24] S. Freire, and M. César, "Inclusive ideals/inclusive practices: How far is a dream from reality? Five comparative case studies," European Journal of Special Needs Education, vol.18, pp.341-354, 2003

[25] T.V. Laarhoven, and D. D. Munk, and K. Lynch, and J. Bosma, and J. Rouse, "A model for preparing special and general education preservice teachers for inclusive education," Journal of Teacher Education, vol.58, pp.440-455, 2007.

[26] K. Nes, "The inclusive school and teacher education: About curricula and cultures in initial teacher education," Paper presented at the International Special Education Congress 2000, Manchester, UK, 2000.

[27] T. Loreman, and C. Earle, "The development of attitudes, sentiments and concerns about inclusive education in a content-infused Canadian teacher preparation program," Exceptionality Education Canada, vol.17, pp.85-106, 2007.

[28] C.S.C. Stella, and C. Forlin, and A.M. Lan, "The influence of an inclusive education course on attitude change of pre-service secondary teachers in Hong Kong," Asia-Pacific Journal of Teacher Education, vol.35, pp.161-179, 2007

[29] A. Burkman, "Preparing novice teachers for success in elementary classrooms through professional development," Professional Development, pp.23-33, 2012.

[30] P. Angelides, and A. Mylordou, "The beneficial outcome of a successfu mentoring relationship: The development of inclusive education," Teacher Development, vol.15, pp.533-547, 2011

[31] L.D. Hobson, and D. Harris, and K. Buckner-Manley, and P. Smith, "The importance of mentoring novice and pre-service teachers: Finding from a HBCU student teaching program," Educational Foundations, pp. 67-80, 2012. 